\title{
Martyria as One of the Christian Aspects of the Helping Worker ${ }^{1}$ Jana Maryšková
}

\section{Introduction}

Martyria, or witness to God, is any action by which Christians testify to their faith in God, by word and deed. ${ }^{2}$ The lexical basis of the word martyria in European languages is etymologically taken from Latin, with an emphasis on pain and suffering. On the other hand, the Greek meaning of the works means witness. The associated terms are martyrion - testimony, evidence; martyrein - to witness, testify; and martys - a witness. ${ }^{3}$

In various places in the Bible the faithful are challenged to witness to their faith, to proclaim the gospel - the good news of God's Kingdom (cf. 1 Pet 3:15b; Mt 28:19f; 10:6-18). Proclamation witnessing to the gospel - can take many forms in contemporary society. Besides education in families, religious instruction, preaching, preparation for Sacramental celebration, it also includes evangelisation by means of radio, television, the internet or the print media, as well as personal witness in everyday life, and the participation of Christians in debates on political and social topics, into which they are expected to bring basic ethical criteria, such as love of God and of neighbour, the Decalogue, the creation of the human being in the image of God, and, not least, Christian commitment wherever human dignity, freedom, peace and solidarity are endangered, since 'evangelisation would not be complete if it did not take account the unceasing interplay of the Gospel and of man's concrete life, both personal and social'. ${ }^{4}$

According to the theologian Leo Karrer, it is necessary to witness to faith at all levels of ecclesial life and in various forms, since when diakonia is connected by means of proclamation - martyria with the Christian message that God has become human and has entered history as one who saves and rectifies - it will become clear that justice, reconciliation and solidarity belong to the essence of being Christian. ${ }^{5}$ Articles 21 and 31 of Paul VI's apostolic exhortation Evangelii nuntiandi speak in a similar manner:

it is impossible to accept 'that in evangelisation one could or should ignore the importance of the problems so much discussed today, concerning justice, liberation, development and peace in the world. This would be to forget the lesson which comes to us from the Gospel

1 The paper was written with financial support of the Grant Agency of the University of South Bohemia, project 157/2016/H, 'Kontexty současné teologie.

Ad gentes 11.

Cf. Pavel AMBROS, Laik a jeho poslání: Mučednictví - svědectví, Olomouc: Refugium, 2011, p. 37; pp. 51-53.

Evangelii nuntiandi 29, 31.

Leo KARRER, Grundvollzüge christlicher Praxis, in: Handbuch Praktische Theologie: Durchführungen, ed. Herbert HASLINGER, Mainz: Matthias-Grünewald, 2000, pp. 390-394. 
concerning love of our neighbour who is suffering and in need' [...] Above all the Gospel must be proclaimed by witness. [...] this witness [...] involves presence, sharing, solidarity. ${ }^{6}$

And as Pope Francis underlines: 'At the very heart of the Gospel is life in community and engagements with others,' ${ }^{7}$ which is why evangelisation has a social dimension and if 'this dimension is not properly brought out, there is a constant risk of distorting the authentic and integral meaning of the mission of evangelisation'.

Martyria is also a task for theology, which is called to 'translate' the witness to God to the language of contemporary human beings and search for ways of transmitting Christian doctrine in new contexts in an intelligible manner 'with the awareness that it must constantly reformulate the Word of God for them over the course of the ages.'

\section{The Christian worker in a helping profession - a Christian or a worker acting in a Christian manner?}

One of the spheres where Christians witness to God in his inclination towards the human being in need are the helping professions, ${ }^{10}$ carried out in ecclesial and non-ecclesial organisations. Speaking of a Christian helping worker, it is generally expected that his motivation for engaging in helping work stems from his Christian faith. But Christians also act upon various motives and the Christian faith can have a negative effect on helping, as M. Opatrný shows in his study. The motivation to helping can then be, for example, the wish to convert the client, proselytising, one's own salvation, etc. ${ }^{11}$ On the other hand a helping worker who is not a faithful Christian can act in a Christian manner, so it is necessary to specify whether the term 'Christian helping worker' is used to mean a Christian or a non-Christian worker acting in a Christian manner.

\subsection{Love of neighbour as a path to an encounter with God}

The pastoral constitution on the Church in the modern world speaks of the conscience as of the 'most secret core and sanctuary' of the human being, in which he detects a law which, although he does not impose it upon himself, he fulfils by loving God and neighbour. ${ }^{12}$ As the constitution further states: 'In fidelity to conscience, Christians are joined with the rest of men in the search for truth, and for the genuine solution to the numerous problems which arise in the life of indivi-

\footnotetext{
Evangelii nuntiandi 21, 31.

Evangelii gaudium 177.

Ibid, 176.

Hans WALDENFELS, Kontextová fundamentální teologie, Praha: Vyšehrad, 2000, p. 48.

10 The helping professions are traditionally divided into several levels, according to the extent in which they are able to help people to solve their social and emotional problems. The so-called first level of helping includes professions such as social workers, psychiatrists, psychologists, marriage consultants, etc., that is, professions in which the focus is primarily on solving social or emotional problems, or both. The second level of helping comprises professions, which work with people in difficult life situations or people going through a crisis. It includes clergy, physicians, nurses, teachers, lecturers and consultants, police persons, probation officers and others. Besides their expertise these workers are capable of helping to cope with the social and emotional dimensions of the situations they solve with their 'clients'. The helping at both levels are professionals. Some authors further distinguish a third and fourth level of helping, on which the help is no longer professional. The third level includes professions such as manager, in which help or advice can be requested by the workers. The fourth level has to do with any human helping - within a family, among neighbours, etc. Cf. Oldřich MATOUŠEK and Pavel HARTL, Nároky sociální práce a syndrom vyhoření, in: Metody ř́zení sociální práce, ed. Oldřich MATOUŠEK, Praha: Portál, 2003, pp. 51-52. In this paper the term 'helping worker' is used to mean a professional at the first or second level of helping.

11 For more detail see Michal OPATRNÝ, Třináctá komnata vztahu teologie a sociální práce: K problematice negativních vlivů křestanské víry na pomáhání, Caritas et veritas: Časopis pro reflexi křestanských souvislostí v humanitních a sociálních oborech 1/2011, pp. 44-59.

12 Cf. Gaudium et spes 16.
} 
duals from social relationships. ${ }^{13}$ Helping one's neighbour, therefore, is not something specifically Christian, because love of neighbour is inscribed into human nature and the Christian faith may, but need not, motivate helping workers to carry out their work. ${ }^{14}$ In the encyclical Deus caritas est Pope Benedict XVI expresses this with the words: 'the command of love of neighbour is inscribed by the Creator in man's very nature. ${ }^{15}$ In article 16 the Pope further states that love of God is inseparable from love of the neighbour, so that to say that we love God becomes a lie if we are closed to our neighbour or hate him altogether. [...] love of neighbour is a path that leads to the encounter with God, and that closing our eyes to our neighbour also blinds us to God. ${ }^{16}$ The Pope's statement shows that even a non-Christian helper can attain an encounter with God through his helping work. Pope Francis speaks in a similar way: 'Any-one who sets off on the path of doing good to others is already drawing near to God, is already sustained by his help, for it is characteristic of the divine light to brighten our eyes whenever we walk towards the fullness of love. ${ }^{17}$ Tomáš Halík offers a similar idea in connection with interpreting the well-known passage about extending efficacious love to the humblest and in them to Christ himself (Mt 25:31-46):

[...] their acts [...] did not have explicit 'Christian' and 'religious' motivation, it is even possible that they were not Christian, not 'faithful'. And if they had faith [...], then it was implicit faith, faith not consisting in 'opinions' and 'convictions', but manifesting itself exclusively in deeds, in life practice. ${ }^{18}$

Here, Halík points out that the primary motivation of the helping activity was not 'proper faith' (orthodoxy), one's own salvation, or fulfilling an obligation, but particular orthopraxy, solidarity with the other, and sensitivity to human suffering.

Heinrich Pompey and Paul-Stefan Roß emphasise that

diakonia is not realised only through Christians! For the people of God is 'greater' than the church and even the helping practice of people who are not members of the visible church or explicit Christians is realised within the horizon of the approaching Kingdom of God. That is why any helping action can have the quality of a diakonic action, even if the acting subjects do not conceive of themselves as Christian. ${ }^{19}$

So, the term 'Christian helping worker' in the sense indicated above can also be applied to someone who is not one of the Christian faithful, but witnesses to Christ by siding with the poor, insignificant, suffering and needy to whom Jesus was sent. By extending neighbourly love he imitates the life of Christ, and by helping others - albeit in a manner unreflected upon - he becomes Christ's disciple. Years ago, Karl Rahner expressed this as follows:

For wherever a profane social deed of society serves the eternal dignity of the person, his freedom and liberation from estrangement from himself, where it enables the human being to be himself and by his own responsibility to create his earthly and eternal fate, where it rids him, as far as possible, of all pre-personal, so that he can receive that which is most difficult: himself in his freedom, there exist social realities that may be, and often are, the body of

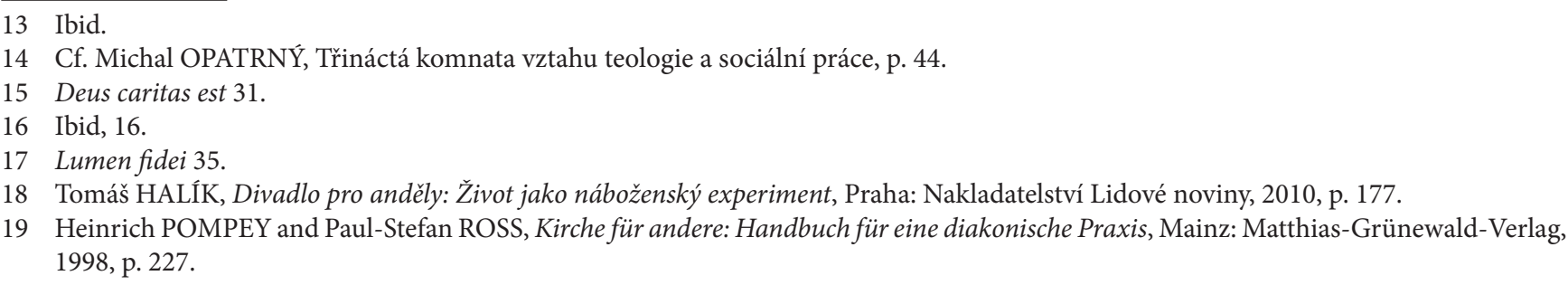


love, and in that way they can, in a special anonymous way, belong to the expression of the Church. $^{20}$

In other words, caritas in a theological sense can be realised even where it is not perceived by the helping workers as such and is not explicitly associated with Christianity. In this context, Pompey and Roß speak of 'implicit', 'anonymous' diakonia, ${ }^{21}$ which is realised wherever humans commit themselves for others and with others in a way corresponding to the Christian conception of help, regardless of whether the helpers are aware of that or not, and whether they aim to do so or not. ${ }^{22}$

\section{2 'Christ's love compels us' (cf. 2 Cor 5:14)}

A Christian helping worker need not necessarily be a Christian, as explained above. But this expression mostly implies the idea of someone whose motivation for helping work derives from his Christian faith. It is assumed that the personal Christian identity of the helping worker is also reflected in his professional identity, i.e., that the helping worker mediates to others his trust in the presence of the liberating and saving God and, by his act of neighbourly love, he lets them experience this liberating and saving presence in their lives. Caritas is therefore constitutive for imitating Jesus and thereby also for all Christian practice of faith. ${ }^{23}$

Pope Francis also speaks of Christian identity. According to the Pope, Christian identity is not a 'nice idea'; it is maintained by the Holy Spirit, who is a 'guarantee and seal. Christians are to have Christ's mind, i.e., Christ's Spirit, not the spirit of this world.

In that their identity consists. Christian identity is visible in witness and the ultimate witness to love and obedience is the cross. St. Paul boasts in the God who became human and died in obedience. That is, according to the Pope, 'identity and at the same time witness. ${ }^{24}$ As the Pope further states: 'Sometimes we are tempted to be that kind of Christian who keeps the Lord's wounds at arm's length. Yet Jesus wants us to touch human misery, to touch the suffering flesh of others. ${ }^{25}$

Therefore, the identity of the Christian helping worker is determined by his relationship to the person and deeds of Jesus Christ. For 'being Christian is not the result of an ethical choice or a lofty idea, but the encounter with an event, a person, which gives life a new horizon and a decisive direction. ${ }^{26}$ The helpers imitate Christ in his self-transcendence, self-giving out of love for the other, because 'Christ's love compels us' (cf. 2 Cor 5:14). 'The consciousness that, in Christ, God has given himself for us, even unto death, must inspire us to live no longer for ourselves but for him, and, with him, for others. ${ }^{27}$ Christian helping workers are led by 'a faith which becomes active through love (cf. Gal 5:6), ${ }^{28}$ or, as the epistle of James states, by faith

20 Karl RAHNER, Praktická teologie a církevní sociální práce, Caritas et veritas 1/2013, pp. 79-80.

21 The term 'anonymous Christian diakonia' has also been used by H. Haslinger, see Herbert HASLINGER, Diakonie zwischen Mensch, Kirche und Gesellschaft: Eine praktisch-theologische Untersuchung der diakonischen Praxis unter dem Kriterium des Subjektseins des Menschen, Würzburg: Echter Verlag, 1996, p. 704.

22 Cf. Heinrich POMPEY and Paul-Stefan ROSS, Kirche für andere, p. 228.

23 Cf. Andreas LOB-HÜDEPOHL, Soziale Arbeit aus christlicher Hand - ein Problemaufriss, Berlin: Berliner Institut für christliche Ethik und Politik, 2005, p. 8.

24 Cf. @ FRANTIŠEK, Křestanská identita není éterická, nýbrž konkrétní (online), at: http://www.radiovaticana.cz/clanek.php4?id=21976, accessed 30th June 2016.

25 Evangelii gaudium 270.

26 Deus caritas est 1.

27 Ibid, 33.

28 Ibid, 31a, 33 
which is 'visible' and can be extended in deeds (cf. Jas 2:14-26). According to Pompey and Roß, 'every Christian who by baptism and confirmation belongs to the people of God realises diakonia by his commitment for others. ${ }^{29}$

In the chapters above I have shown that the term 'Christian helping worker' need not apply only to a Christian; it can also be used to refer to a non-Christian helper whose action is 'implicitly' Christian. For the purposes of this paper the term 'helping worker' or 'Christian helping worker' is used to refer to a Christian for whom the life and death of Jesus Christ is an expression of service to others and the source of his own motivation for serving his neighbour, which is expressed in a particular helping action. At the same time, this term is used to denote a professional, not in the sense of necessary professional competence, but also pastoral competence, which 'enables him to actively react to existential, religious and ethical contexts of the client's problem. ${ }^{30}$

\section{The helping worker as a martyr of God}

As stated in the previous chapter, Christian helping workers testify to their faith by imitating Christ in his inclination towards the human being in need, in respecting his dignity and individuality, and thereby become witnesses of God's love, God's closeness and compassion that have been manifested in Christ. 'The duty of Christians to take part in the life of the Church impels them to act as witnesses of the Gospel and of the obligations that flow from it. This witness is a transmission of the faith in words and deeds. ${ }^{31}$ The helping worker is a witness - a martyr of God in several aspects.

\subsection{The helping worker as a martyr of God's kenosis}

'God is love', says the apostle John (cf. 1 John 4:8), and it is precisely the serving and self-emptying love that is a path to meeting God. 'The history of the world is a struggle between two forms of love: love of oneself - up to destroying the world; and love for the other - up to renouncing oneself. ${ }^{32}$ It is God, who loved us first and still loves us in the same way. That is why we are also able to respond with love, which is manifested in serving the needy (cf. 1 John 4:10-12). And it is precisely love for the other which is capable of 'going out of oneself towards the other and towards his situation ${ }^{33}$ that is one of the levels at which the helping worker becomes a martyr of God. This going out of oneself imitates

the Father's going out of himself in the eternal act of begetting the Son, God's going out of himself in the act of creation, God's going out of himself and his bowing down to the human being in the work of Revelation and especially in the work of the Incarnation. The genuineness of this going out of oneself out of love for the other is unsurpassably manifested in Christ's going out of himself out of love for the Father and for humans in the hour of his freely accepted death on the cross. ${ }^{34}$

29 Cf. Heinrich POMPEY and Paul-Stefan ROSS, Kirche für andere, p. 225.

30 Jakub DOLEŽEL, Co dělá sociální práci křestanskou?, in: Teorie a praxe charitativní práce: Uvedení do problematiky. Praktická reflexe a aplikace, ed. Michal OPATRNÝ and Markus LEHNER et al., České Budějovice: Jihočeská univerzita v Českých Budějovicích, 2010, p. 24.

31 Catechism of the Catholic Church 2472.

32 BENEDICT XVI and Peter SEEWALD, Licht der Welt: Der Papst, die Kirche und die Zeichen der Zeit, Freiburg im Breisgau: Herder, 2010, p. 79.

33 Ctirad Václav POSPÍŠIL, Teologie služby, Kostelní Vydř́: Karmelitánské nakladatelství, 2002, p. 56.

34 Ibid. 
Raimon Panikkar does not hesitate to speak of the "cross of the Trinity": In the Father the apophaticism (kenosis or emptying) of being is real and all-encompassing [...]; it is the perfect sacrifice of God (Father), which has been revealed and depicted in Jesus's cross and in his self-sacrifice. ${ }^{35}$ Kenosis is an attitude of true love, because it means giving space to the other, giving preference to him and 'decreasing' oneself (cf. John 3:30). So, love for the other requires self-giving and repeated self-renunciation, and it means imitating Jesus in total self-giving (cf., for example, Mt 1:17; Lk 10:37): 'God's Kingdom comes in human weakness and powerlessness. Of course, it happens in no other way than at the cost of human risky self-commitment and self-giving, by which the human being reacts to the challenge presented by Jesus' story. ${ }^{36}$

This requires the helping worker to commit himself personally and 'step out' of his professional role (whether as physician, nurse, psychologist, social worker, etc.). The professional role secures respect, and makes it possible to maintain a distance from the others, which disables a genuine encounter with the human being in a situation of need. What is necessary, therefore, is not only professional competence, but also the willingness to imitate Christ's 'going out of himself' out of love for the neighbour. 'For to imitate Christ means to give up power, descending with him to the depth of human suffering, of human need, and to become a sacrament of God's love, of God's compassion with the human being. ${ }^{37}$

The requirement of radically imitating Jesus (cf. Mk 1:17; Lk 10:37; Jn 13:15) also means giving up all security and a willingness to self-commitment and self-giving out of love for the other, even up to martyrium. At present, the transmission of faith is associated especially with personal witness and it is therefore necessary that Christians

at first with their lifestyle and subsequently also with their words become internally focused on the reasons for their hope (cf. 1 Pet 3:15), even at the cost of persecution, unjustified murder and inexplicable human suffering borne with the trust that the hope of the past arouses hope of the future. ${ }^{38}$

Present-day martyrs are not only Christians who took a stand against the Nazi and communist totalitarian regimes and became victims of those repressive regimes, but currently, for example, also the four young Christian workers murdered in 2014 in East Ukraine by pro-Russian separatists, ${ }^{39}$ or the four sisters - Missionaries of Charity - murdered together with their wards on $4^{\text {th }}$ March 2016 in Yemen, ${ }^{40}$ about whom Pope Francis said:

These are the martyrs of today! They do not appear on front pages of journals, they are not a topic of reporting. They shed their blood for the Church. They are victims of those who committed the attack, but also of indifference, of this globalisation of indifference, which doesn't care. ${ }^{41}$

Among these mundane martyrs there are also Christian humanitarian workers, teachers, nurses and physicians helping in third-world countries, whose

35 Raimon PANIKKAR, Trojice: O mystické sounáležitosti mezi lidmi, Brno: Cesta, 1998, p. 83.

36 Quoted according to Jan RÜCKL and Petr ŠTICA ed., Bonaventura Bouše: Odkaz a vzpomínky, Praha: Vyšehrad, 2009 , p. 40.

37 Ctirad Václav POSPÍŠIL, Teologie služby, p. 188.

38 Pavel AMBROS, Laik a jeho poslání: Mučednictví - svědectví, p. 67.

39 (c) HLAS MUČEDNÍKŮ, Ukrajina: Čtyři mladí misionáři zavražděni (online), at: http://www.hlas-mucedniku.cz/pnp.php?datum =2014-08-21, accessed 8th March 2016 .

40 (C) TISKOVÉ STŘEDISKO ČBK, Papež k útoku na Misionářky Lásky: To jsou mučednice dneška (online), at: http://tisk.cirkev.cz/zezahranici/papez-k-utoku-na-misionarky-lasky-to-jsou-mucednice-dneska, accessed 8th March 2016.

41 Ibid. 
martyrdom is the supreme witness given to the truth of the faith; it means bearing witness even unto death. The martyr bears witness to Christ who died and rose, to whom he is united by charity. [...] He endures death through an act of fortitude. ${ }^{42}$

In this self-giving, in renouncing themselves out of love for the other, which is a selfless gift of oneself, in setting their lives at stake for others, in this kenosis, which is a pre-requisite of a genuine inter -personal relationship, the helping worker is a witness - a martyr of the relationships in the community of Persons of the Most Holy Trinity and as a disciple of Christ is a martyr of Christ Jesus, who,

though he was in the form of God, did not count equality with God a thing to be grasped, but emptied himself, taking the form of a servant [...], humbled himself and became obedient unto death, even death on a cross. (Phil 2:6-8)

\subsection{The helping worker as a martyr of God's con-solatio}

In his encyclical Spe salvi Pope Benedict XVI asks whether the other person is so important for us that we are willing to become for him a person who suffers, because even love, which requires renunciation of the self, can become a source of suffering. Often the human being strives to avoid suffering, to avoid all that could present suffering, to spare the effort and pain associated with truth, love and goodness. The Pope asks whether we are capable of that and whether love really promises so much that it justifies personal self-giving. ${ }^{43}$ In response to this question, Benedict XVI states that it is the merit of Christian faith in human history that has awoken in the human being a new and deeper ability to suffer and at the same time has shown that truth, justice and love are not mere ideals, but potent realities. ${ }^{44}$

The Christian faith has shown us that truth, justice and love are not simply ideals, but enormously weighty realities. It has shown us that God - Truth and Love in person - desired to suffer for us and with us. Bernard of Clairvaux coined the marvellous expression: Impassibilis est Deus, sed non incompassibilis - God cannot suffer, but he can suffer with. Man is worth so much to God that he himself became man in order to suffer with man in an utterly real way - in flesh and blood - as is revealed to us in the account of Jesus's Passion. Hence in all human suffering we are joined by one who experiences and carries that suffering with us; hence con-solatio is present in all suffering, the consolation of God's compassionate love and so the star of hope rises. ${ }^{45}$

So, this com-passion, co-suffering (compassio) represents first of all the ability of identifying with the other, of an understanding empathy on the part of the helping worker. It is not a matter of sympathetically pitying the one who is being helped, but of walking together, co-feeling, co-experiencing suffering analogically to God's incarnation in Jesus Christ, who entered human life with its magnificence and misery, and shared and co-bore all human suffering. Accepting the other in his suffering then means, to a certain extent, adopting his suffering, identifying with it and becoming a witness of God's con-solatio. ${ }^{46}$ This being-together-in-loneliness thus represents another level at which the helping worker becomes God's martyr, because in it he mediates God's closeness,

\footnotetext{
Catechism of the Catholic Church 2473.

Cf. Spe salvi 38, 39.

Ibid, 39.

Ibid.

Ibid, 38, 39 .
} 
God's compassionate love and hope for the suffering person.

If the helping worker is a Christian, then his fundamental task is to be God's witness to other people (Acts 2:22-32) and to represent this God's con-solatio: he is a witness - a martyr, who by his co-suffering with the sufferer refers to God's co-suffering with this sufferer. Ultimately, it is no other principle than the one founding the Anointing of the Sick, when it represents God's compassion and assistance to the sick person. [...] So even the simple co-being of the helping worker with the suffering person as a testimony of his co-suffering with this human being can be a sign and an instrument of the intrinsic union of God with humans and of humans with God in suffering - regardless of that person's level of faith and knowledge of Christian doctrine. Of course, this is conditioned by the trustworthiness of such a witness, i.e., by the absolute unity of his words and acts. ${ }^{47}$

If the helping worker shares, co-bears suffering then that suffering is permeated by his presence and the love of light shines through it. ${ }^{48}$ The Latin word con-solatio, consolation, 'suggests being with the other in his solitude, so that it ceases to be solitude.49

If Jesus - the incarnate Son of God - in the ultimate hour of his service to humanity experienced our desertedness, then he is also mysteriously present in each of our desertedness, he is 'God with us' even when we are feeling deeply deserted. ${ }^{50}$

By his sympathy, his co-suffering, empathetic listening and silence the helping worker is thus a witness - a martyr to this mysterious presence of God in silence and solitude.

\subsection{The helping worker as a martyr of God's transformative power}

God himself entered history, became a human being and suffered; he became 'God-with-us', who shared not only our life, but also our pains, suffering and death. And Jesus' death is the most radical expression of God's desire to be 'God-with-us'. That is why 'the true measure of humanity is essentially determined in relationship to suffering and to the sufferer. ${ }^{51}$ But the human being 'cannot accept another's suffering unless he personally is able to find meaning in suffering, a path of purification and growth in maturity, a journey of hope. ${ }^{2}$ As John Paul II states in his apostolic letter Salvifici doloris,

in whatever form, suffering seems to be, and is, almost inseparable from man's earthly existence. [...] Suffering [...] manifests in its own way that depth which is proper to man, and in its own way surpasses it. Suffering seems to belong to man's transcendence: it is one of those points in which man is in a certain sense 'destined' to go beyond himself, and he is called to this in a mysterious way. ${ }^{53}$

And the helping worker in his work becomes a witness to the internal transformation of the human being in a deep life crisis, becomes a martyr of God's mysterious and transformative power in the human being.

\footnotetext{
Michal OPATRNÝ, Impassibilis est Deus, sed non incompassibilis (sv. Bernhard z Clairvaux): Srovnání pohledů Jana Pavla II. a Benedikta XVI. na utrpení z pastorálního hlediska, Theologos 1/2011, p. 67.

48 Cf. Spe salvi 38.

49 Ibid.

50 Ctirad Václav POSPÍŠIL, Teologie služby, p. 58.

51 Spe salvi 38.

52 Ibid.

53 Salvifici doloris 2, 3.
} 
Article 16 of the pastoral constitution Gaudium et spes says that the human being has God's law engraved in his heart and can listen to God's voice in his conscience - 'the most secret core and sanctuary. ${ }^{54}$ Article 22 then says that every human being is connected to the Paschal mystery in a way known to God alone. ${ }^{55}$ In this context, Tomáš Halík in his book Night of the Confessor points out an interesting aspect of the Christian faith:

When someone takes on and honestly bears his human lot, with patience towards its limitedness and finitude, in a constant quest for meaning, and especially in love and solidarity with others, then by this existential affirmation of his humanity he at the same time touches on the mystery of the Incarnation. [...] By taking seriously our own humanity and the humanity of others in all of its weakness, imperfection, fragility and finitude, we are through this honest humanity 'aboard one ship' with those who confess and imitate Christ, the Word of God, which has taken human nature upon itself. ${ }^{56}$

The fact that God's grace invisibly works in human hearts, regardless of whether they believe in Christ or not, and that every human being participates in the Paschal mystery implies that every human being is also capable of experiencing himself as a place of God's activity, which holds especially in extreme life situations, in which the question of meaning is raised with a greater intensity. With his attitude the helping worker can help the other to internally transform his pain and suffering, and to endow it with meaning.

It is necessary to help the suffering person to identify, intrinsically and altogether freely, as much as possible with the liberating attitude of the Crucified, which transforms suffering from within, and in that way to give his suffering an altogether new meaning. Perfect acceptance of the attitude of the Crucified transforms particular suffering into a mysterious representation of Christ's cross in this place and moment. ${ }^{57}$

For this, the helping worker needs, besides expert competence, to be truthful, open, unbiased, authentic, to respect the other, and to unconditionally accept him as he is, regardless of his behaviour or appearance. All of that can be subsumed under the theological category of love grounded in God's love, which places no conditions on its closeness and the helping activity. Helping a human being in an extreme life situation always requires an individual attitude, patient and attentive listening, and empathy, when 'our heart experiences something of the pain which the sufferer is experiencing in his own body and in his own heart. ${ }^{58}$ Besides that, our attitude of respect for the human being in need ought to manifest what value and dignity he himself has for us. 'Our true sympathy, our co-suffering, our attentive and listening silence, all that in fact imitates the behaviour of God the Father in the hour of the cross. ${ }^{59}$ Taking Christ's cross on oneself is enormously difficult, because it involves transcending oneself and completely handing oneself over to 'the One who is since eternity a gift of the self to the very bottom..$^{60}$ That is why

someone who wants to talk about suffering, its meaning and its Christian value, really ought to balance every word [...]. Superficial, shortcut interpretations of Jesus's suffering and our

\footnotetext{
Cf. Gaudium et spes 16.

Cf. ibid, 22.

Tomáš HALÍK, Noc zpovědníka: Paradoxy malé víry v postoptimistické době, Praha: Nakladatelství Lidové noviny, 2005, p. 58.

Ctirad Václav POSPÍŠIL, Teologie služby, p. 192.

Ibid, p. 194.

59 Ibid, p. 195
}

60 Ibid. 
participation in it will not help, they will more likely do harm. ${ }^{61}$

To bear suffering, whatever its cause, means to become open to the efficacy of God's transformative and saving power,

which endows the human being already in this life with wonderful dignity. It is not simple even for a faithful Christian, but even a person with a pure heart who does not believe in Christ can approach such an attitude, albeit he will name the mystery taking place in him in his own way. ${ }^{62}$

A human being who freely accepts toil and the pains of life is assimilated to the suffering Christ, 'shares in this love, [...] rediscovers himself more and more fully in suffering: he rediscovers the "soul" which he thought he had "lost" because of suffering. ${ }^{63}$ By their welcoming, patient, empathetic attitude to the human being in a life crisis while unconditionally respecting his state, not only physical but also in its emotional hardships, by assistance in the search for orientation in connection with the meaning of what the person is experiencing, helping workers send out an important signal and feedback, not only to human beings in need and all those who help them but also to society as a whole, concerning the value and quality of human life. In his apostolic letter Salvifici doloris, John Paul II writes:

Down through the centuries and generations it has been seen that in suffering there is concealed a particular power that draws a person interiorly close to Christ, a special grace. [...] A result of such a conversion is not only that the individual discovers the salvific meaning of suffering but above all that he becomes a completely new person. He discovers a new dimension, as it were, of his entire life and vocation. This discovery is a particular confirmation of the spiritual greatness which in man surpasses the body in a way that is completely beyond compare. When this body is gravely ill, totally incapacitated, and the person is almost incapable of living and acting, all the more do interior maturity and spiritual greatness become evident, constituting a touching lesson to those who are healthy and normal. ${ }^{64}$

When human beings in difficult life situations are able to transform their suffering and bear it with an intrinsic peace, patience and serenity, they become a help and a model for others similarly afflicted, as well as for helping workers. Their attitude can bring others to reflect upon their life, to re-evaluate life priorities and to gain a deeper insight into their own life. At the same time, they give those who provide them with expert help the possibility to participate in their sufferings, to share their fears, anxieties and pain, to become witnesses - martyrs - of God's transformative efficacy and reach a mature attitude not only towards life, but also to dying and death. But such an internal transformation requires 'often a long process of one's own conversion and the grace of the Crucified, ${ }^{\prime} 5$ which culminates in the internal maturity and spiritual greatness of the sufferer. As John Paul II, whose pontificate from the very beginning was associated with a deep interest in the poor, the ill and the suffering, wrote in his inauguration encyclical Redemptor hominis, 'man is the way for the Church'.6 ${ }^{6}$ The Pope further developed and amended the idea in his apostolic letter Salvifici doloris, where he wrote that 'man in a special fashion becomes the way for the Church

61 Aleš OPATRNÝ, Pastorační péče v méně obvyklých situacích, Praha: Pastorační středisko sv. Vojtěcha při Arcibiskupství Pražském, 2005, p. 28.

62 Ctirad Václav POSPÍŠIL, Teologie služby, p. 192.

63 Salvifici doloris 23.

64 Ibid, 26.

65 Michal OPATRNÝ, Impassibilis est Deus, sed non incompassibilis, p. 61.

66 Redemptor hominis 14. 
when suffering enters his life, ${ }^{3}$ in whatever period of life and whatever form, and the Church, 'born of the mystery of Redemption in the Cross of Christ, [...] has to try to meet man in a special way on the path of his suffering', 68 because 'in this meeting man "becomes the way for the Church", and this way is one of the most important ones. ${ }^{69}$ In his post-synodal apostolic letter Christifideles laici John Paul II, who 'regarded suffering experienced with Christ and for Christ as a great and salvation-producing good, which is capable of enriching the whole community of the Church, ${ }^{70}$ further states that

the suffering individual is the way of the Church because that person is, first of all, the way of Christ Himself, who is the Good Samaritan who 'does not pass by', but 'has compassion on him, went to him [...] bound up his wounds [...] took care of him' (Lk 10,32-34). ${ }^{71}$

The mission of the Church is to serve human beings, ${ }^{72}$ especially human beings in need, which is why, as 'Christ united himself with her in his mystery of Redemption, the Church must be strongly united with each man, ${ }^{73}$ who 'is and always becomes the "way" for the Church's daily life..74

\section{Conclusion}

At the centre of the helping service of Christian helping workers there is always - in the spirit of the pastoral constitution Gaudium et spes - the human being with his joys and hopes, fears and anxieties; ${ }^{75}$ the human being, seen from a Christian point of view as created by God in God's image and likeness (Gen 1:26), as man and woman (Gen 1:27) who mutually complement each other, who both hold the same dignity based on the fact that the human being is a person, is a 'relational' being capable of having a personal relationship with God and other humans (Gen 2); the human being is a free being, who is entrusted with care of other creatures and the created world, as well as with responsibility for his neighbour, ${ }^{76}$ whose life remains finite, despite all scientific and technological progress, and is threatened in many diverse ways. The main meaning and goal of Christian-motivated care for the needy therefore ought to be making God known, so that human beings in this world would not be living and dying in this world without God, [...] exposed to final despair, ${ }^{77}$ mediating the hope that the world and the human being in it are not left to their fate, because God 'if we are faithless, he remains faithful - for he cannot deny himself' (2 Tim 2:13), and the salvation of the human being, 'whole and entire, body and soul, heart and conscience, mind and will: ${ }^{78}$

Workers in the helping professions meet people in extreme situations of life, in which these people experience fear, loneliness, despair, resignation and grief. The crisis affects all components of

67 Salvifici doloris 3 .

68 Ibid.

69 Ibid.

70 Stanisław DZIWISZ and Czesław DRĄŻEK, Utrpení v životě a papežském úřadu Jana Pavla II., in: Stanisław DZIWISZ, Czesław DRĄŻEK, Renato BUZZONETTI and Angelo COMASTRI, Síla v slabosti Jana Pavla II., Kostelní Vydří: Karmelitánské nakladatelství, 2006, p. 17.

71 Christifideles laici 53

72 Gaudium et spes 3.

73 Redemptor hominis 18

74 Ibid, 21.

75 Cf. Gaudium et spes 1.

76 Cf. PAPEŽSKÁ BIBLICKÁ KOMISE, Bible a morálka: Biblické kořeny křest’anského jednání, Kostelní Vydří: Karmelitánské nakladatelství, 2010, pp. 18-19; 21-22.

77 Lumen gentium 16.

78 Gaudium et spes 3. 
the human being: bodily, mental, spiritual, existential and social. An extreme life situation confronts the human being with his own vulnerability, finitude, transience; it casts doubt on certitude and places the human being face to face with fundamental existential questions, which are at the same time questions of a religious nature, even though they need not necessarily be formulated in the 'language of faith. Christian helping workers witness to their faith in God by imitating Christ in his inclination to the human being in need, in respecting his dignity and individuality, and thereby become witnesses - martyrs of God's love, God's closeness and compassion manifested in Christ, as well as of God's mysterious transformative and saving power in the human being.

\title{
Martyria as One of the Christian Aspects of the Helping Worker
}

\begin{abstract}
The paper deals with the topic of martyria as one of the Christian aspects of the helping worker. In the first part, the paper focuses on defining the term 'Christian helping worker' and answering the question of whether that label signifies a Christian worker or a worker acting in a Christian way. In the second part, the paper discusses the Christian helping worker's task to be God's witness - martyr - to other people. It shows three aspects of such witness: the helping worker as a martyr of God's kenosis, as a martyr of God's con-solatio, and finally as a martyr of God's transformative power in the human being.
\end{abstract}

Keywords: martyria, helping worker, Christian helping worker, God's martyr, kenosis, consolatio

\section{Author contact}

Jana Maryšková MA et MA

University of South Bohemia in České Budějovice

Faculty of Theology, Department of Ethics, Psychology and Charity Work

Kněžská 8, 37001 České Budějovice

marysj00@tf.jcu.cz 